\title{
Occurrence of immature forms of culicids (Insecta: Diptera) in the northeastern region of Brazil
}

\author{
Ocorrência de formas imaturas de culicídeos (Insecta: Diptera) na região nordeste do Brasil \\ Cristiane Maia da Silva ${ }^{1,2}$; Henrique Silva Sérvio ${ }^{2}$; Rafael Antonio Nascimento Ramos ${ }^{2,3}$; \\ Maria Aparecida da Gloria Faustino²; Leucio Câmara Alves²; Gílcia Aparecida de Carvalho ${ }^{4 *}$ \\ ${ }^{1}$ Programa de Pós-graduaçáo em Ciência Animal Tropical, Universidade Federal Rural de Pernambuco - UFRPE, Recife, PE, Brazil \\ ${ }^{2}$ Departamento de Medicina Veterinária, Universidade Federal Rural de Pernambuco - UFRPE, Recife, PE, Brazil \\ ${ }^{3}$ Dipartimento di Medicina Veterinaria, Università degli Studi di Bari, Valenzano, Italy \\ ${ }^{4}$ Unidade Acadêmica de Garanhuns - UAG, Universidade Federal Rural de Pernambuco - UFRPE, Garanhuns, PE, Brazil
}

Received January 17, 2014

Accepted April 16, 2014

\begin{abstract}
The Culicidae family is represented by approximately 3,610 species, among which many are involved in transmission of pathogens and parasites, thus presenting great medical-veterinary importance. In Brazil, the state of Pernambuco is considered an endemic area for many diseases vectored by mosquitoes, such as human and canine filariasis, caused by Wuchereria bancrofti and Dirofilaria immitis, respectively. The aim of this study was to evaluate the occurrence of immature forms of culicids, over an one-year period, in a specific area of northeastern region of Brazil. Culicids larvae were collected from traps located on the ground and in treetops, between october 2012 and september 2013. Ten different species of culicids were identified. The greatest number of larvae were collected in september 2013 and the lowest number in december 2012. Stegomyia (Stegomyia) albopicta (46.45\%; 5,908/12,718), Culex (Culex) maxi (35.56\%; 4,523/12,718) and Limatus durhamii (12.58\%; 1,600/12,718) were the most frequent species. The human and animal populations living in the study area are exposed to culicids and transmission agents throughout the year, especially after the rains. Therefore, control and prevention measures against culicids must be adopted in the study area.
\end{abstract}

Keywords: Mosquitoes, seasonal, abundance, vectors, Culicidae.

\section{Resumo}

A família Culicidae é representada por aproximadamente 3.610 espécies, dentre as quais muitas estão envolvidas na transmissão de patógenos e parasitos, apresentando assim grande importância médico-veterinária. No Brasil, o Estado de Pernambuco é considerado área endêmica para diversas doenças transmitidas por mosquitos como, por exemplo, as filarioses humana e canina causadas pela Wuchereria bancrofti e Dirofilaria immitis, respectivamente. O objetivo deste estudo foi avaliar a ocorrência de formas imaturas de culicídeos durante um ano em uma área do Nordeste do Brasil. Larvas de culicídeos foram coletadas em armadilhas localizadas no solo e copa de árvores, no período de outubro de 2012 a setembro de 2013. Dez diferentes espécies de culicídeos foram identificadas, sendo o maior número de larvas coletadas em setembro de 2013 e o menor número em dezembro de 2012. Stegomyia (Stegomyia) albopicta (46,45\%; 5.908/12.718), Culex (Culex) maxi (35,56\%; 4.523/12.718) e Limatus durhamii (12,58\%; 1.600/12.718) foram as espécies mais frequentes. A população humana e animal residente na área de estudo é exposta aos culicídeos e aos agentes por eles veiculados durante todo o ano, sobretudo após o período de chuvas. Portanto, medidas de controle e prevenção dos culicídeos devem ser adotadas na área estudada.

Palavras-chave: Mosquitos, sazonal, abundância, vetores, Culicidae.

\section{Introduction}

The Culicidae family is represented by nearly 3,610 species, among which approximately 150 species belonging to the genus Culex, Aedes, Anopheles and Haemagogus are involved in transmission

\footnotetext{
*Corresponding author: Gílcia A. Carvalho

Unidade Acadêmica de Garanhuns - UAG, Universidade Federal Rural de Pernambuco - UFRPE, Av. Bom Pastor, s/n., Boa Vista, CEP 55292-270,

Garanhuns, PE, Brasil

e-mail: gilciasilva@yahoo.com.br
}

of pathogenic agents to animals and humans (GUEDES, 2012). The immature forms of these culicids develop in aquatic environments that are present in domestic, peridomestic and forest areas. Some species, such as Culex (Culex) quinquefasciatus, may develop in water containing decomposing organic material, such as in small pits and sewage areas, while others, such as Stegomyia (Stegomyia) aegypti and Stegomyia (Stegomyia) albopicta, use a variety of objects (e.g. tires, cans, bottles, plates and vases, water tanks, buckets, 
bamboo cavities and bromeliad tanks) containing water with smaller quantities of decomposing organic material and salts, as their breeding grounds (CONSOLI; OLIVEIRA, 1994).

Culicids have great medical-veterinary importance because they are vectors of different pathogens and parasites that cause diseases (e.g. arboviruses, protozoa and helminths) (CARVALHO et al., 2013; DIBO et al., 2011; FORATTINI, 2002; PINTO et al., 2011). In Brazil, the state of Pernambuco is considered an endemic area for several pathogens transmitted by mosquitoes. For example, human filariasis, caused by Wuchereria bancrofti, has been a serious sanitary problem in Recife (the state capital) and adjacent areas for a long time (FONTES et al., 2012; MEDEIROS et al., 2006). Similarly, canine filariasis caused by Dirofilaria immitis, a parasite with zoonotic potential, is frequently reported in northeastern region of Brazil, including the state of Pernambuco (ALVES et al., 1999; CARVALHO et al., 2008, 2013; SILVA; LANGONI, 2009).

Close contact between culicids and human/animal populations, in regions characterized as fragments of forests embedded in urban or rural environments, facilitates transmission of pathogenic agents, being the humans easily involved in enzootic cycles of infectious and parasitic diseases (MONTES, 2005). Considering the sanitary importance of these invertebrates, studies on their occurrences in certain areas are essential for providing information about the periods of risk to populations, and also for gathering data that is useful in effectively controlling these vectors. Therefore, the aim of this study was to evaluate occurrences of immature forms of culicids, over an one-year period, in a specific area of northeastern region of Brazil.

\section{Materials and Methods}

\section{Area of study}

The study was carried out in a remnant portion of the Atlantic Forest ( $8^{\circ} 17^{\prime} 15^{\prime \prime}$ south and $35^{\circ} 02^{\prime} 00^{\prime \prime}$ west), covering an area of approximately 3 hectares, located in the municipality of Cabo de Santo Agostinho (Pernambuco, northeastern region of Brazil). The study area was partly damaged by the construction of a dam, but still has areas of virgin forest. It is characterized by secondary vegetation and is crossed by the Pirapama river. The climate is hot and humid, with an average annual temperature of $25^{\circ} \mathrm{C}$ and average relative air humidity of $73.5 \%$.

Temperature, relative air humidity and precipitation data during the study period (from October 2012 to September 2013) were obtained from the Pernambuco Technology Institute (Instituto de Tecnologia de Pernambuco, ITEP).

\section{Collection and identification of culicids}

Third and fourth-instar culicid larvae were collected every week from artificial breeding grounds, between October 2012 and September 2013, totaling 48 collections during the whole study. For this, 23 traps constructed from plastic (PET) bottles that were cut and painted black, were distributed in domestic $(n=5)$, peridomestic ( $n=5$; three on the ground and two at the treetops) and forest environments ( $\mathrm{n}=13$; six on the ground and seven spread out across the treetops) (Figure 1), with distances of 20 meters between the traps. The treetop traps were positioned at a height of $2 \mathrm{~m}$ from the ground.

The larvae thus collected were transported in plastic vials containing water and were then identified in the laboratory. They were mounted between a slide and a coverslip, and viewed through an optical microscope (at magnifications of $10 \mathrm{X}$ and 40X). Larval samples (10\%) from each breeding ground was maintained in a colony (at temperature conditions of $25 \pm 2{ }^{\circ} \mathrm{C}$ and relative air humidity of $80 \pm 5 \%$ ) until adults were obtained, in order to confirm the species. The larvae and adults were identified in accordance with previously proposed dichotomous keys (ALMIRÓN; HARBACH, 1996; CONSOLI; OLIVEIRA, 1994; FORATTINI, 1965, 2002).

The abbreviations used for the genus and subgenus are presented according to Reinert (2009).

\section{Data analysis}

The data obtained were subjected to descriptive statistical analysis, and the influence of climate variations on the culicid population fluctuation was evaluated through correlation coefficient analysis. The chi-square test with Yates correction $\left(x^{2}\right)$ was used to compare culicid occurrences with the collection environments (domestic, peridomestic and forest), as well as the locations in these environments (ground and treetops). The significance level was taken to be 5\%. The BioEstat software, version 2.0 for microcomputers, was used to make statistical calculations (AYRES et al., 2000).

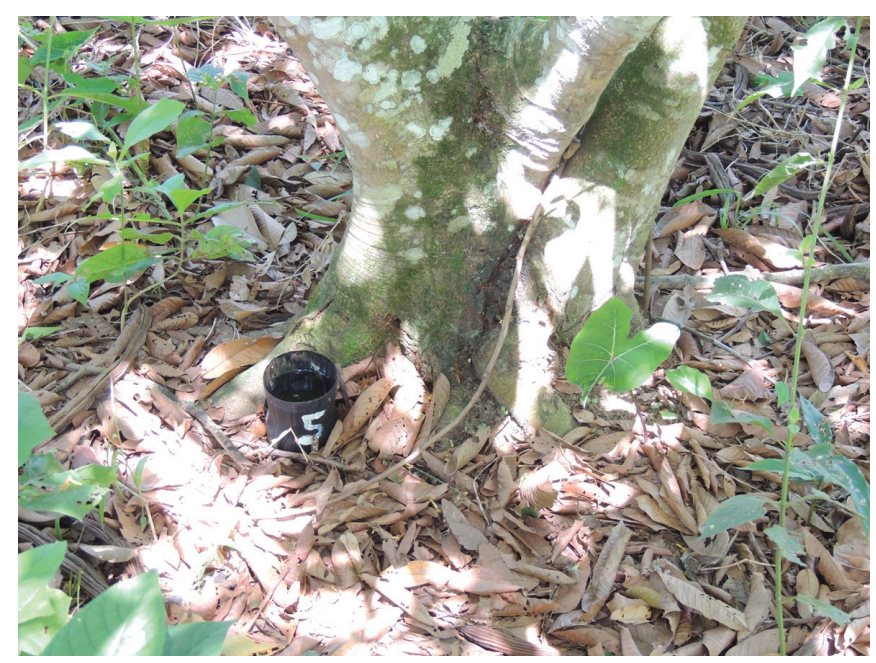

Figure 1. Trap constructed from plastic (PET) bottle, located in the forest environment on the ground. 


\section{Results}

A total of 12,718 culicid larvae (average of 1,059.83 specimens/ month) were collected during the study, and they were detected in all months of the year (Figure 2). The highest number of specimens was detected in September $2013(\mathrm{n}=4,084)$ and the lowest in December $2012(\mathrm{n}=86)$. In particular, 2,441 (19.2\%), $7,098(55.9 \%)$ and 3,179 (24.9\%) larvae were collected in the domestic, peridomestic and forest areas, respectively. With regards to the positioning of traps (peridomestic and forest areas), 8,585 specimens $(67.5 \%)$ were collected from the ground and 1,692 (13.3\%) from treetops.

Ten different species of culicids were identified, being $S$. (S.) albopicta (46.45\%; 5,908/12,718), Culex (Culex) maxi (35.56\%;

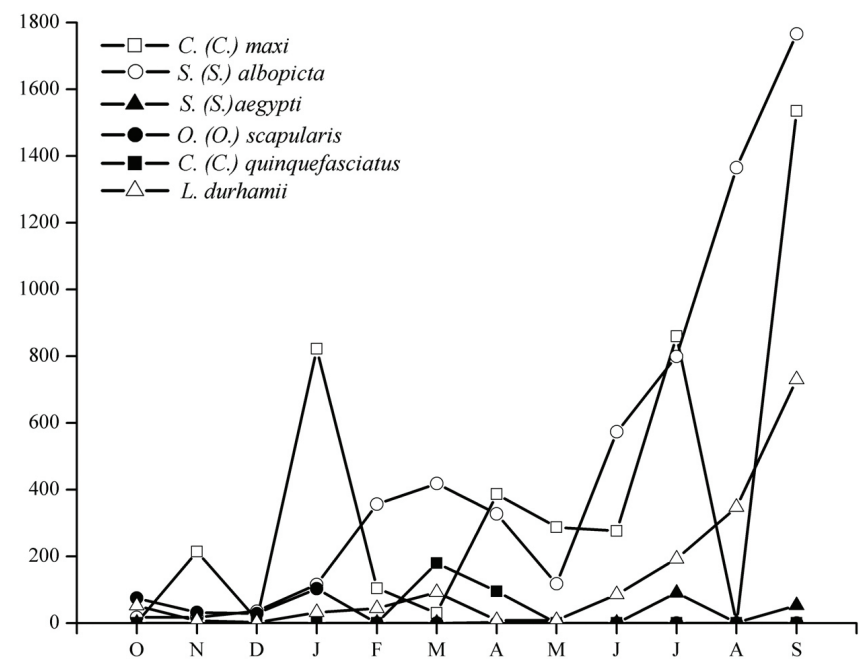

Figure 2. Occurrence of immature forms of culicids at Cabo de Santo Agostinho from October 2012 to September 2013.
4,523/12,718) and Limatus durhamii (12.58\%; 1,600/12,718) the most frequent (Table 1).

In the traps distributed in the domestic environments, the species $S$. (S.) albopicta predominated (95.58\%; 2,333/2,441), while in those positioned in the peridomestic areas, the species $C$. (C.) maxi predominated on the ground $(73.22 \% ; 4,523 / 6,177)$ and S. (S.) albopicta in the treetops $(97.94 \% ; 902 / 921)$. In the traps located in the forest areas, several species were found: L. durhamii predominated on the ground $(50.33 \% ; 1,212 / 2,408)$, while $S$. $(S$.) albopicta was also found in large numbers on the ground $(38.12 \%$; $918 / 2,408)$ and predominated in the treetops $(55.71 \%$; 430/771). Ochlerotatus (Ochlerotatus) scapularis, Anopheles (Kerteszia) bellator, Anopheles (Nyssorhynchus) braziliensis and Mansonia (Mansonia) titillans were found exclusively in the peridomestic area, whereas C. (C.) quinquefasciatus was found in the forest area (Table 1).

The results showed that $S$. $(S$.) albopicta colonized all three environments, predominating in the domestic and peridomestic areas, which did not differ statistically from each other $\left(x^{2}=2,417\right.$; $\mathrm{p}=0.1200)$ but differed from the forest environment (domestic: $x^{2}=263,042 ; \mathrm{p}=0.0000 ;$ peridomestic: $x^{2}=215,632 ; \mathrm{p}=0.0000$ ) The species $L$. durhamii also colonized all three environments, but predominantly in the forest environment, which differed statistically from the other environments $\left(x^{2}=41,397 ; \mathrm{p}=0.0000\right)$. $S$. (S.) aegypti was detected in the domestic and peridomestic areas, but predominantly in the domestic environment $\left(x^{2}=24,490\right.$; $\mathrm{p}=0.0000)$.

In comparing the culicids' preference for trap location (ground or treetops) in the three environments, it was observed that $S$. (S.) albopicta presented greater frequency in the traps installed on the ground in the peridomestic areas and also in the forest, with a statistical difference $\left(x^{2}=26,591 ; \mathrm{p}=0.0000\right)$. L. durhamii was also predominantly observed in traps placed on the ground, especially those installed in the forest $\left(x^{2}=4,357 ; \mathrm{p}=0.0369\right)$.

The species were more abundant at medium temperatures ranging from $24.6{ }^{\circ} \mathrm{C}$ to $27.2^{\circ} \mathrm{C}$ (Figure 3), with relative air

Table 1. Immature forms of culicids collected from traps located in different areas (domestic, peridomestic and forest) in Pirapama, Cabo de Santo Agostinho, Pernambuco, from October 2012 to September 2013.

\begin{tabular}{|c|c|c|c|c|c|c|c|c|c|c|c|}
\hline \multirow{3}{*}{ SPECIES } & \multicolumn{11}{|c|}{ ENVIRONMENT } \\
\hline & \multicolumn{2}{|c|}{ DOMESTIC } & \multicolumn{4}{|c|}{ PERIDOMESTIC } & \multicolumn{4}{|c|}{ FOREST } & \multirow[b]{2}{*}{ Total } \\
\hline & AF & $\begin{array}{l}\text { RF } \\
(\%) \\
\end{array}$ & $\begin{array}{l}\text { Ground } \\
\text { (AF) }\end{array}$ & $\begin{array}{l}\text { RF } \\
(\%)\end{array}$ & $\begin{array}{c}\text { Treetop } \\
\text { (AF) }\end{array}$ & $\begin{array}{l}\mathrm{RF} \\
(\%)\end{array}$ & $\begin{array}{l}\text { Ground } \\
\text { (AF) }\end{array}$ & $\begin{array}{l}\text { RF } \\
(\%) \\
\end{array}$ & $\begin{array}{c}\text { Treetop } \\
\text { (AF) }\end{array}$ & $\begin{array}{l}\text { RF } \\
(\%) \\
\end{array}$ & \\
\hline Stegomyia (Stegomyia) albopicta & 2,333 & 95.58 & 1,325 & 21.45 & 902 & 97.94 & 918 & 38.12 & 430 & 55.78 & 5,908 \\
\hline Culex (Culex) maxi & 0 & 0 & 4,523 & 73.22 & 0 & 0 & 0 & 0 & 0 & 0 & 4,523 \\
\hline Limatus durbamii & 4 & 0.16 & 36 & 0.60 & 18 & 1.95 & 1,212 & 50.33 & 330 & 42.80 & 1,600 \\
\hline Culex (Culex) quinquefasciatus & 0 & 0 & 0 & 0 & 0 & 0 & 275 & 11.42 & 0 & 0 & 275 \\
\hline $\begin{array}{l}\text { Ochlerotatus (Ochlerotatus) } \\
\text { scapularis }\end{array}$ & 0 & 0 & 238 & 3.90 & 0 & 0 & 0 & 0 & 0 & 0 & 238 \\
\hline Stegomyia (Stegomyia) aegypti & 104 & 4.26 & 43 & 0.70 & 0 & 0 & 0 & 0 & 0 & 0 & 147 \\
\hline Toxorhynchites spp. & 0 & 0 & 0 & 0 & 1 & 0.11 & 3 & 0.13 & 11 & 1.42 & 15 \\
\hline Anopheles (Kerteszia) bellator & 0 & 0 & 8 & 0.13 & 0 & 0 & 0 & 0 & 0 & 0 & 8 \\
\hline $\begin{array}{l}\text { Anopheles (Nyssorhynchus) } \\
\text { braziliensis }\end{array}$ & 0 & 0 & 3 & 0.0 & 0 & 0 & 0 & 0 & 0 & 0 & 3 \\
\hline Mansonia (Mansonia) titillans & 0 & 0 & 1 & 0.0 & 0 & 0 & 0 & 0 & 0 & 0 & 1 \\
\hline TOTAL & 2,441 & 100 & 6,177 & 100 & 921 & 100 & 2,408 & 100 & 771 & 100 & 12,718 \\
\hline
\end{tabular}

AF - Absolute Frequency; RF - Relative Frequency. 

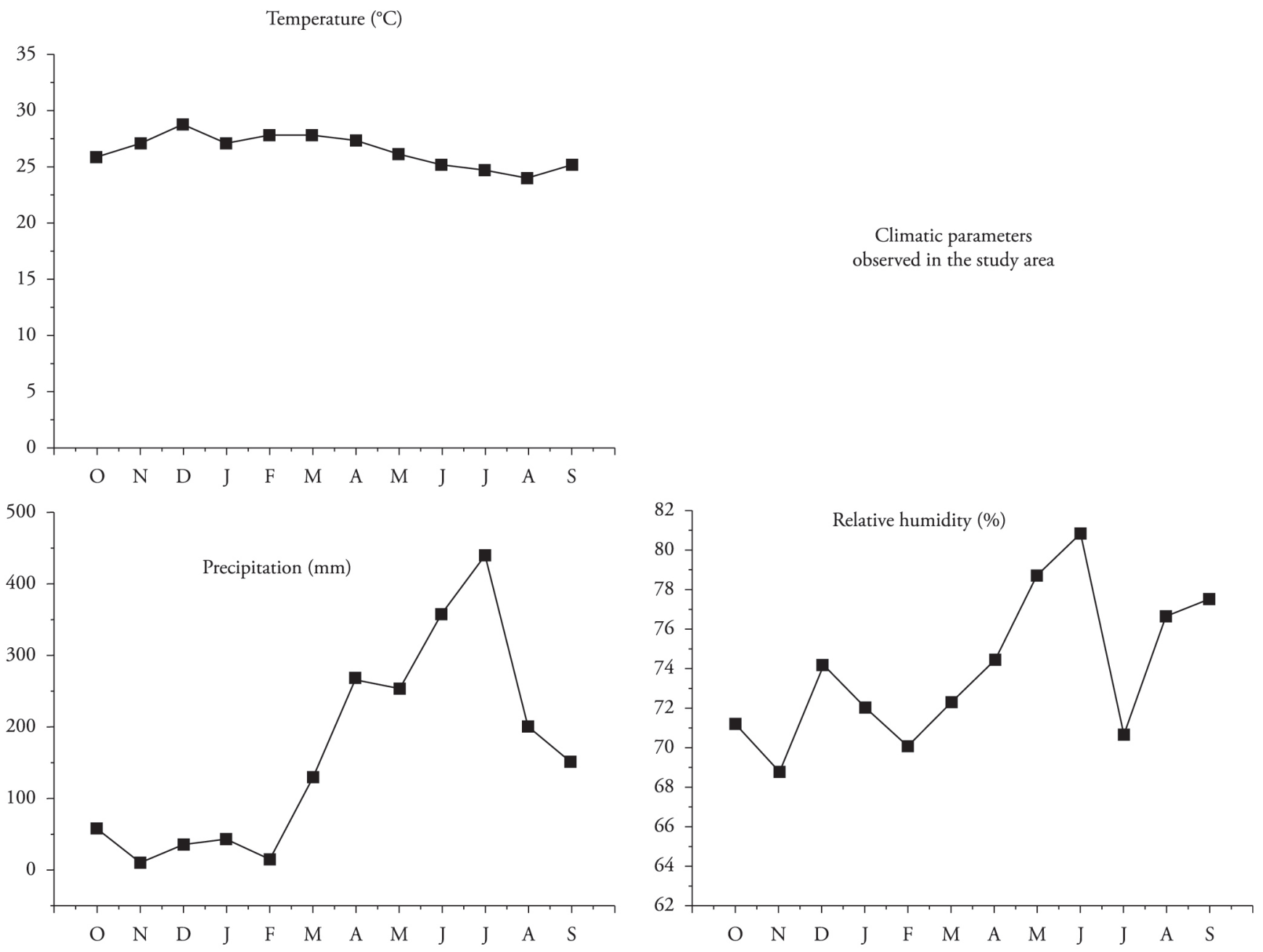

Figure 3. Climatic conditions observed in the study area from October 2012 to September 2013.

humidity between $72.0 \%$ and $80.8 \%$. The precipitation varied greatly, from $44.8 \mathrm{~mm}$ to $440.1 \mathrm{~mm}$ per month. In correlating occurrences of species with climatic variables, a weak correlation was found between precipitation and relative air humidity $(\mathrm{r}<$ 0.33 and $r<0.30$, respectively). With regard to temperature, the correlation was negative and moderate $(r<0.50)$.

The average monthly temperature ranged from $25.1{ }^{\circ} \mathrm{C}$ (October 2012) to $28.8{ }^{\circ} \mathrm{C}$ (December 2012). The relative air humidity ranged from $68.7 \%$ (November 2012) to 80.8\% (June 2013). The driest months were November 2012 and February and July 2013. The average monthly precipitation oscillated from $9.9 \mathrm{~mm}$ (November 2012) to $440.1 \mathrm{~mm}$ (July 2013), such that the months of November 2012 and February 2013 were the months with least precipitation, and the months of June and July 2013 were the most rainy. During the study, a period of intense drought occurred in the area, thus making the climatic conditions atypical.

\section{Discussion}

This study evaluated occurrences of culicid larvae in an area with a tropical climate (northeastern Brazil) over an one-year period. Larvae were found during all months of the year, and were most frequent in the month of September 2013. In general, the study showed larval population peaks between the months of January and April, and between June and September.

The population fluctuations of culicid species in this study were probably related to the different environments from which they were collected (domestic, peridomestic and forest), and to the particular features of each species, such as their adaptation and better development under different climatic conditions. Considering that in this area the temperature and air humidity variations are minimal over the course of the year, it is most likely that precipitation levels play an important role in the population of culicids. The influence of climatic parameters on culicid larval abundance has been reported previously, presenting different results in many cases. For instance, the abundance of C. (C.) quinquefasciatus in the city of Córdoba (Argentina) was not correlated with variables such as temperature and rainfall (ALMIRÓN; BREWER, 1996), while in Buenos Aires, the larval plethora of Culex (Culex) pipiens was positively associated with the mean weekly temperature (FISCHER et al., 2000; FISCHER; SCHWEIGMANN, 2004).

It is known that the risk of pathogen transmission is higher when the culicid population increases. In this study, the species 
S. (S.) albopicta presented two populational peaks, firstly from February to April and secondly from June to September, coinciding with the populational peaks of $C$. $(C$.) quinquefasciatus and $S$. ( $S$.) aegypti, respectively. It is likely that the larval abundance of culicids was not determined by a single climatic parameter, but by an association of variables such as environmental degradation and the diverse distribution of rainfall.

Although larvae were collected from all three study areas (i.e. domestic, peridomestic and forest), they were predominantly found in the peridomestic area. In addition, the specimens were more frequently found in the traps positioned on the ground than in those on treetops. These variations were probably related to the biological behavior of each species. Interestingly, $O$. $(O$.) scapularis, $A$. (K.) bellator, $A$. (N.) braziliensis and $M$. (M.) titillans were found exclusively in the peridomestic area, whereas $C$. $(C$.) quinquefasciatus was found in the forest area. Notwithstanding, larvae of $O$. (O.) scapularis are predominantly found in natural breeding sites at ground level, collection of these larvae from artificial sites has already been reported (FORATTINI, 2002). The retrieval of $C$. (C.) quinquefasciatus exclusively from forest areas may be related to the fact that this species is collected predominantly from shaded breeding sites. Thus, the forest environment presents suitable conditions for this species to develop.

Interestingly, the study area presented marked environmental degradation, which contributed to alterations in the natural breeding sites of Culicidae species. For instance, larvae that are commonly restricted to forest environments may be collected in domestic/peridomestic areas (GOMES et al., 1999). This transition between the forest and domestic environments involves several mosquito species, which may play important roles in the wild epidemiological life cycles of pathogens, thus representing an important threat to public health.

Overall, a great variety of culicid species was observed, but three of them were more representative, i.e. $S$. (S.) albopicta, C. (C.) maxi and L. durhamii. Curiously, S. (S.) albopicta was the only species detected throughout the study (i.e. in all months of the year). The ability of the eggs of this species to tolerate desiccation (FORATTINI, 2002) is likely to have contributed towards maintaining the viability of this species throughout the year in the study area. Two populational peaks (from February to April and from June to September) were observed for this species. Therefore, occurrences of this species seem to be related to rainfall, since the two populational peaks overlap with the period of rains reported here. This species presents great epidemiological importance due to its capacity to be a vector for various arboviruses (TAIPE-LAGOS; NATAL, 2003). Moreover, S. (S.) albopicta is a potential vector for the dengue virus, which causes epidemic disease throughout Brazil, and for $D$. immitis, the etiological agent of canine dirofilariasis, which also has a zoonotic nature (CARVALHO et al., 2013). This culicid species was detected in traps in all three environments (domestic, peridomestic and forest), thus confirming its capacity to colonize a wide variety of artificial breeding grounds, without necessarily abandoning its natural ecotopes (GOMES et al., 1999).

Although $C$. (C.) maxi was described in the state of Pernambuco only recently (RAMOS et al., 2011), the great number of larvae detected here indicates that this mosquito species is well adapted to the environmental conditions present in the study area. It was the second most abundant species throughout the study, and its abundance was closely related to the rainy season, as observed in a previous study in Buenos Aires, Argentina (FISCHER; SCHWEIGMANN, 2004). Considering that this species has been reported to be an important vector of arboviruses in other regions (FORATTINI, 1998), its vector capacity in the region studied here needs to be investigated.

On the other hand, the species $L$. durhamii, which is typical of forest areas (FORATTINI, 2002), was also found in the domestic and peridomestic environments. This finding demonstrates the domiciliation of this species, as previously reported in the southeastern region of Brazil (REZENDE et al., 2011). Similar behavior was observed for $O$. (O.) scapularis (formerly typical of forest areas), which was detected in peridomestic areas. Studies have indicated that this species is adapted to anthropic environments, especially areas modified by human beings (BRANCO et al., 2009; TAIPE-LAGOS; NATAL, 2003). The finding of a high number of $L$. durhamii specimens during the rainy period corroborates with what was reported by LIRA-VIEIRA et al. (2013) in the central-western region of Brazil. Similarly, a higher number of $O$. (O.) scapularis larvae were detected with increasing rainfall and reached zero with reduced rainfall. These data differ from those of a previous study, in which a higher numbers of $O$. (O.) scapularis larvae were collected during the dry period (LIRA-VIEIRA et al., 2013). The presence of $O$. (O.) scapularis in this area is of great importance, particularly considering that in previous studies, it was suggested that this species was a vector for $D$. immitis (ALVES et al., 1999) and W. bancrofti (MEDEIROS et al., 2006) on the coast of Pernambuco (same area of study). Similarly, the presence of $A$. $(K$.) bellator in this area is relevant, considering its importance as a vector of protozoa of the genus Plasmodium (FORATTINI et al., 1999). Indeed, the possibility that monkeys might be infected by Plasmodium that affects humans and vice versa has been confirmed, thus demonstrating the zoonotic potential of these parasites (ARAÚJO et al., 2013).

From an epidemiological perspective, development of species originally from forest areas in domestic and peridomestic areas represents a risk for the populations residing in these areas, since they are exposed to different diseases transmitted by culicids, such as dengue, yellow fever, Venezuelan equine encephalitis, human and canine filariasis and Rocio encephalitis (BRANCO et al., 2009; FORATTINI et al., 1995; FORATTINI, 2002; NUNES et al., 2008). The last disease mentioned (i.e. Rocio encephalitis) is considered an important emergent zoonosis that is endemic in some regions of Brazil. Although this disease is little known, humans affected by it present rigidity in the neck, mental confusion and balance disorders. Moreover, birds, marsupials and rodents are natural reservoirs of its etiological agent (NUNES et al., 2008).

Although $S$. (S.) albopicta, the most frequent species studied in the area (i.e. Cabo de Santo Agostinho, Pernambuco), presented two populational peaks - from February to April and from June to September - it is possible to conclude that the animal and human populations residing in the area of study were exposed to culicids and to the agents throughout the year, especially after the rainy period. Therefore, culicid control and prevention measures need to be adopted in the study area in order to reduce the impact on health caused by the endemicity of the species reported here. 


\section{References}

Almirón WR, Brewer ME. Classification of immature stage habitats of Culicidae (Diptera) collected in Córdoba, Argentina. Mem Inst Oswaldo Cruz 1996; 91(1): 1-9. http://dx.doi.org/10.1590/S007402761996000100001

Almirón WR, Harbach RE. Taxonomy and biology of Culex (Culex) maxi Dyar (Diptera: Culicidae) in South America. Mem Inst Oswaldo Cruz 1996; 91(5): 579-88. http://dx.doi.org/10.1590/S007402761996000500008

Alves LC, de Almeida Silva LV, Faustino MA, McCall JW, Supakonderj P, Labarthe NW, et al. Survey of canine heartworm in the city of Recife, Pernambuco, Brazil. Mem Inst Oswaldo Cruz 1999; 94(5): 587-90. PMid:10464398. http://dx.doi.org/10.1590/ S0074-02761999000500004

Araújo MS, Messias MR, Figueiró MR, Gil LH, Probst CM, Vidal NM, et al. Natural Plasmodium infection in monkeys in the state of Rondônia (Brazilian Western Amazon). Malar J2013; 12: 180. PMid:23731624 PMCid:PMC3680335. http://dx.doi. org/10.1186/1475-2875-12-180

Ayres M, Ayres M Jr, Ayres DL, Santos AL. BioEstat 2.0: Aplicaçôes estatísticas nas áreas das ciências biológicas e médicas. Manuas: Sociedade Civil Mamirauá; Brasília: CNPq; 2000. 272 p.

Branco AS, Mendes-de-Almeida F, Faria MCF, Souza-Dantas LM, Labarthe NV. Dirofilaria immitis (Leidy, 1856) no entorno de um caso felino: um estudo sobre sua transmissão. Rev Bras Parasitol Vet 2009; 18(S1): 14-8. PMid:20040185. http://dx.doi.org/10.4322/ rbpv.018e1003

Carvalho GA, Alves LC, Maia RT, Andrade CFS, Ramos RAN, Faustino MAG. Vector competence of Culex quinquefasciatus Say, 1823 exposed to different densities of microfilariae of Dirofilaria immitis (Leidy, 1856). Rev Bras Entomol 2008; 52(4): 658-62. http://dx.doi.org/10.1590/ S0085-56262008000400018

Carvalho GA, Maia RT, Ramos RAN, Andrade CFS, Faustino MAG, Alves LC. Evaluation of larval development of Dirofilaria immitis in different populations of Aedes aegypti and Aedes albopictus. OJVM 2013; 3(6): 277-81. http://dx.doi.org/10.4236/ojvm.2013.36045

Consoli RAGB, Oliveira RL. Principais mosquitos de importância sanitária no Brasil. Rio de Janeiro: Fiocruz; 1994. 225 p.

Dibo MR, Menezes RMT, Ghirardelli CP, Mendonça AL, Chiaravalloti Neto F. Presença de culicídeos em município de porte médio do Estado de Sáo Paulo e risco de ocorrência de febre do Nilo Ocidental e outras arboviroses. Rev Soc Bras Med Trop 2011; 44(4): 496-503. PMid:21860898. http://dx.doi.org/10.1590/S0037-86822011000400019

Fischer S, Marinone MC, Fontanarrosa MS, Nieves M, Schweigmann N. Urban rain pools: seasonal dynamics and entomofauna in a park of Buenos Aires. Hydrobiologia 2000; 441(1): 45-53. http://dx.doi. org/10.1023/A:1017591122911

Fischer S, Schweigmann N. Culex mosquitoes in temporary urban rain pools: seasonal dynamics and relation to environmental variables. $J$ Vector Ecol 2004; 29(2): 365-73. PMid:15707296.

Fontes G, Leite AB, de Lima AR, Freitas H, Ehrenberg JP, da Rocha EM. Lymphatic filariasis in Brazil: epidemiological situation and outlook for elimination. Parasit Vectors 2012; 5: 272-83. PMid:23181663 PMCid:PMC3545725. http://dx.doi.org/10.1186/1756-3305-5-272

Forattini OP, Kakitani I, Massad E, Marucci D. Studies on mosquitoes (Diptera: Culicidae) and anthropic environment. 9- Synanthropy and epidemiological vector role of Aedes scapularis in South-Eastern Brazil. Rev Saúde Pública 1995; 29(3): 199-207. PMid:8539531. http://dx.doi. org/10.1590/S0034-89101995000300007
Forattini OP, Kakitani I, Santos RLC, Ueno HM, Kobayashi KM. Role of Anopheles (Kerteszia) bellator as malaria vector in Southern Brazil (Diptera: Culicidae). Mem Inst Oswaldo Cruz 1999; 94(6): 715-8. PMid:10585643. http://dx.doi.org/10.1590/S0074-02761999000600001

Forattini OP. Culicidologia médica: identificação, biologia, epidemiologia. São Paulo: EDUSP; 2002. 860 p.

Forattini OP. Entomologia médica: Culicini: Culex, Aedes e Psorophora. São Paulo: Editora da USP/Faculdade de Higiene e Saúde Pública; 1965. v. 2.

Forattini OP. Mosquitos Culicidae como vetores emergentes de infecçóes. Rev Saúde Pública 1998; 32(6): 497-502. PMid:10349140. http://dx.doi. org/10.1590/S0034-89101998000600001

Gomes AC, Bitencourt MD, Natal D, Pinto PLS, Mucci LF, Paula $\mathrm{MB}$, et al. Aedes albopictus em área rural do Brasil e implicaçóes na transmissão de febre amarela silvestre. Rev Saúde Pública 1999; 33(1): 95-7. http://dx.doi.org/10.1590/S0034-89101999000100012

Guedes MLP. Culicidae (Diptera) no Brasil: relaçôes entre diversidade, distribuiçăo e enfermidades. Oecologia Australis 2012; 16(2): 283-96. http://dx.doi.org/10.4257/oeco.2012.1602.07

Lira-Vieira AR, Gurgel-Gonçalves R, Moreira IM, Yoshizawa MA, Coutinho ML, Prado PS, et al. Ecological aspects of mosquitoes (Diptera: Culicidae) in the Gallery Forest of Brasilia National Park, Brazil, with an emphasis on potential vectors of Yellow Fever. Rev Soc Bras Med Trop 2013; 46(5): 566-74. PMid:24142367. http://dx.doi. org/10.1590/0037-8682-0136-2013

Medeiros Z, Alves A, Brito JA, Borba L, Santos Z, Costa JP, et al. The present situation regarding lymphatic filariasis in Cabo de Santo Agostinho, Pernambuco, Northeast Brazil. Rev Inst Med Trop São Paulo 2006; 48(5): 263-7. PMid:17086313. http://dx.doi.org/10.1590/ S0036-46652006000500005

Montes J. Fauna de Culicidae da Serra da Cantareira, São Paulo, Brasil. Rev Saúde Pública 2005; 39(4): 578-84. PMid:16113907. http://dx.doi. org/10.1590/S0034-89102005000400010

Nunes TC, Ribeiro RS, Faria PRGV, Silva NJ Jr. Vetores de importância Médica na área de influência da pequena central Hidrelétrica MosquitãoGoiás. Estudos 2008; 35(11-12): 1085-105.

Pinto DM, Ribeiro PB, Vianna EES. Culicídeos associados a bovinos de leite, no sul do Rio Grande do Sul, Brasil. Arq Bras Med Vet Zootec 2011; 63(5): 1251-4. http://dx.doi.org/10.1590/S010209352011000500031

Ramos RAN, Costa GJA, Carvalho GA, Faustino MAG, Alves LC. First record of Culex (Culex) maxi Dyar (Diptera: Culicidae) in Pernambuco state, Brazil. Arq Inst Biol 2011; 78(4): 623-4.

Reinert JF. List of abbreviations for currently valid generic-level taxa in family Culicidae (Diptera). Europ Mosq Bull 2009; 27: 68-76.

Rezende HR, Virgens TM, Liberato MA, Valente FI, Fernandes A, Urbinatti PR. Aspectos ecológicos de culicídeos imaturos em larvitrampas de floresta e ambiente antrópico adjacente no Município de Linhares, Espírito Santo, Brasil. Epidemiol Serv Saúde 2011; 20(3): 385-91. http:// dx.doi.org/10.5123/S1679-49742011000300013

Silva RC, Langoni H. Dirofilariose. Zoonose emergente negligenciada. Cienc Rural 2009; 39(5): 1614-23. http://dx.doi.org/10.1590/S010384782009005000062

Taipe-Lagos CB, Natal D. Abundância de culicídeos em área metropolitana preservada e suas implicaçóes epidemiológicas. Rev Saúde Pública 2003; 37(3): 275-9. PMid:12792675. 